\title{
EARNING QUALITY AFTER IFRS ADOPTION (STUDY ON INDONESIAN GO PUBLIC COMPANIES THAT ARE LISTED ON IDX)
}

\author{
Amalia Rizki a, Riska Nur Rosyidiana ${ }^{\mathrm{b}}$ \\ ab University of Airlangga, Surabaya, Indonesia \\ Corresponding email: amalia.rizki@feb.unair.ac.id
}

\begin{abstract}
This study's objective is to find out whether IFRS implementation has considerable implication by examined factors that affecting earning quality such as beta, capital structure, earning persistence, growth opportunities and firm size in the fair value accounting environment in Indonesia, since Indonesia has implemented IFRS since 2012. This research attempts to be part of development and application groundwork in implementing knowledge and theory, continuing studies about IFRS and its application in Indonesia. The sample which will be used is manufacturing companies that are listed in Indonesian Capital Stock Exchange (IDX) in 2011. This study will be conducted by cross sectional approach using 2011-2014 data. The data will be analysed by multiple regression analysis models. The result shows that all variables are not affecting partially and simultaneously to the earning quality.
\end{abstract}

Keywords: IFRS Implementation, Indonesia, Indonesian Capital Stock Exchange, Manufacturing Companies.

\section{Research Background}

Minimizing geography borders across countries in terms of free trade and investment brings us to the establishing of one financial system and global stock market. It forced the harmonization of accounting and financial reporting that have to be done by every country, including Indonesia as the widely users of financial reporting. Historical cost that was introduced by Paton and Littleton in 1940 had been used for decades as a generally accepted basis of accounting. However, the alternative valuation bases have become more common today. The publicity of International Financial Reporting Standards (IFRS) by International Accounting Standards Board (IASB), has been bringing a turning point to the refreshed direction of financial reporting. At the moment, more than 100 countries have been entailed on preparation financial statements under IFRS. Generally speaking, there is a gradually movement of standards from historical cost accounting to current cost alternatives today.

Market reaction to earnings information depends on the quality of profits generated by the company. The strong market reaction to earnings information is reflected in the high Earning Response Coefficient, indicating that reported earnings quality, and vice versa, the lack of market reaction to information means low Earning Response Coefficient. Earning Response Coefficient measures the extent of a security's abnormal market return in response to unexpected component of reported earnings of the form issuing that security (Scott, 2009, p. 154). Kormendi and Lipe (1987), Easton and Zmijewski (1989), and Dhaliwal et al. (1991) using a factor such as Beta, Capital Structure, Persistence, and Growth Opportunities. In fact, all of those factors has been proven under the basis of historical based measurement.

Ball (2006) stated that there's a focus of IFRS on fair value accounting that may also lead to increased earnings volatility and consequently, less accurate earnings forecasts. Hence, a lot of further researches need to be conducted in determining the prior research relevance in the fair value accounting environment. In coexistence with Ball (2006), Preiato et al. (2009) implied that it was unclear that mandatory IFRS adoption would in fact result in an increase in the decision usefulness of financial statement information. 


\section{Asia Pacific Journal of Advanced Business and Social Studies \\ ISBN (eBook): 9780994365675 | ISSN : 2205-6033 \\ Year: 2017, Volume: 3, Issue: 2}

Investors also think of firm size as one of the factors in selecting the stocks that fit on them. According to Chaney and Jeter (1991), the corporation that is bigger tends to have higher Earning Response Coefficient compare to the smaller corporation because big corporations tend to have bigger earnings.

In Indonesia, the implementation of PSAK (Indonesian Financial Accounting Standards) that is already adopting IFRS has started in 2012. According to Purba (2010, p. 44), there are three problems regarding fully adopting of IFRS in Indonesia. First problem is, DSAK as a board that is obliged to set financial accounting standard in Indonesia, has not ready to prepare the fully adoption of IFRS. The second problem is that Indonesian rules of law probably do not fit in IFRS. The third problem is that the human resources and the education system in Indonesia has not ready to change into IFRS. Purba also argued that Indonesian government has not seriously react to the corporate financial reporting system. The Indonesian Institute of Accountants' decision to adopt IAS and IFRS fully is also concerned will not giving positive effect to the investor.

The study of earning quality had been performed by some researchers in Indonesia. Mulyani et al. (2007) studied factors that affect earning quality, that is represented by earning response coefficient. The dependent factors are earning persistence, capital structure, systematic risk, growth opportunities, firm size, and auditor quality. The period of observation is between 2000-2005. The result shows that earning persistence, capital structure, systematic risk, growth opportunities, and firm size is affecting ERC, and auditor quality is not affecting earning quality. Naimah and Utama (2006) studied factors that affecting earning response coefficient and book value of equity response coefficients. They used firm size, earning persistence, growth, negative earnings, profitability, and accounting bias as a dependent factor, with the period of observation between 1994-2002. The result shows that firm size, earning persistence, growth, and profitability is affecting positively while negative earnings, and accounting bias affect negatively. However, the studies were conducted on Indonesian companies that are listed on the Indonesia stock exchange under historical cost based accounting.

As a preliminary study, Sunardi and Rizki (2012) examined factors that affect earning quality on fair value accounting environment in Australian Securities Exchange using four years post-IFRS implementation in financial sector, because Australia has implemented IFRS since 2005. The sample consists of 83 diversified financial firms that listed on Australian Securities Exchange (ASX) 2007-2010. The result shows that only growth opportunities affect Earning Response Coefficient. However, it is noted that Australia has different type of securities market compared with Indonesia's. It can be presumed that the result will be different.

Based on the factors that was used by previous researchers and the firm size, examination about the validity of Scott's explanation in the context of fair value in accounting, using Indonesian Stock Exchange as the proper place where it can be conducted. Since Indonesia started to implement IFRS in 2012 (the 2011 annual reports), this continuing research will be conducted in cross sectional using annual reports of public companies from 2011-1014. This research objective is to find out the impact of Beta, Capital Structure, Earning persistence, Growth Opportunity, and Firm Size to the Earning Quality.

Some contributions that can be attained from this research are: as a development and application groundwork in implementing knowledge and theory; as a continuing study about IFRS and its application in Indonesia; to give information to investor of oversee the capability as a base of doing the investment; and to give information and illustration to the 
company in making financial decision making that affecting above factors in the fair value accounting.

\section{Theoretical Review}

Scott (2009, p. 100) stated, it should be apparent that informed investors would want to move quickly upon receipt of new information. If they do not, other investors will get there first and the market value of the securities in question will adjust so as to reduce or eliminate the benefit of the new information. An efficient securities market is one where the prices of securities traded on that market at all times fully reflect all information that is public known about those securities. Three points are particularly noteworthy. First, market prices are efficient with respect to public known information. Secondly, the market is efficient relative to stock public available information. A third implication is that investing is fair game if the market is efficient. This means that investors cannot expect to earn excess returns on a security, or portfolio of securities, over and above the normal expected return allows for risk.

According to PSAK 1 (IAI, 2012), a financial statement is a structured statement of financial position and financial performance of an entity. The objectives of financial statement are to give information about entities' financial position, financial performance, and cash flow that are useful for the users of financial statement in making economic decisions. Financial statements are prepared to provide information about financial condition of a corporation. In Statement of Financial Accounting Concept, (SFAC) No.1 (FASB, 1978) it said that financial statement must provide information that:

- helps in making investment and credit decisions.

- enables assessing future cash flows.

- users to learn about economic resources, claims against those resources, and changes in them.

However, financial statements do not provide all the information that users may need to make decisions since they largely portray the financial effects of past events and do not necessarily provide non-financial information. Financial statements also show the results of the stewardship of management, or the accountability of management for the resources entrusted to it.

According to PSAK 1, earning information is needed to evaluate the economical resource in the future, produce cash inflow from the current resources, and to formulate decision making about corporate effectively in using addition resources (IAI, 2009). For the shareholder and/or investor, earning means the increase of wealth, which is obtained through the dividend payment. Earninga are also used as a tool to measure management performance in a certain period of time, and also it has become measurement to evaluate management effort in managing its resources which is entrusted to them, also used to determine its going concern in the future.

For investors, earning information is very important to analyze stocks. From several information derived from the financial statement, usually earning becomes the focus of the user (Beattie et al. 1994.). Earnings which are published can give various responses that showing market reaction to the earning information (Cho \& Jung, 1991). The reaction given depends on the earning quality of the corporation.

Statement of Financial Accounting Concepts No. 1 (SFAC No. 1) states "Financial reporting should provide information about an enterprise's financial performance during a period." In Borrowing language from SFAC No. 1, we define earnings quality as follows: Higher quality 


\section{Asia Pacific Journal of Advanced Business and Social Studies \\ ISBN (eBook): 9780994365675 | ISSN : 2205-6033 \\ Year: 2017, Volume: 3, Issue: 2}

earnings provide more information about the features of a firm's financial performance that is relevant to a specific decision made by a specific decision-maker.

According to Dechow et al. (2010), there are three features in earnings quality.

- Earnings quality is conditional on the decision-relevance of the information.

- The quality of a reported earnings number depends on whether it is informative about the firm's financial performance, many aspects of which are unobservable.

- Earnings quality is jointly determined by the relevance of underlying financial performance to the decision and by the ability of the accounting system to measure performance. On the contrary, in the practical environment, earning quality is difficult to measure.

Many foreign researchers who have been researching the scope of earnings, such as Ball and Brown (1968), revealed that the content of information with the analysis when changes to the unexpected positive earnings have abnormal rate of return on average positive and if it does not have information content that is negative, then have the abnormal rate of return on average negative. Capital markets focused on the determinants of ERC. Since several decades, the relationship between the market reactions to accounting variables has been a topic of interest to researchers as well as for investors and company managers. Some research indicates that the ERC varies in cross sectional as Biddle and Seow (1991) and Lipe (1990). Researchers indicate that the ERC depends on the level of earnings persistence, earnings predictability, and covariant stock market return, the growth of enterprise and industry characteristics.

Interest in the ERC as a topic of research is most clearly traced to the market reaction literature. The term 'ERC' has been used in some research to describe the coefficient on the earnings variable in regressions of returns on earnings, but now more commonly used to describe the coefficient on unexpected earnings in regressions of abnormal returns on that variable (Collins and Kothari ,1989; Easton and Zmijewski, 1989).

According to Scott (2009, p. 154), Earning Response Coefficient measures the extent of a security's abnormal market return in response to unexpected component of reported earnings of the form issuing that security. A number of reasons can be suggested for differential market response to report earning is beta, capital structure, earnings quality, growth opportunities, the similarity of investor expectation and the information of price.

Cho and Jung (1991) defined the ERC as an impact of every dollar of unexpected earnings upon stock return, and usually are measured by coefficient slope in abnormal return regression and unexpected earnings from abnormal return average level. It shows that ERC as a reaction of profit announcement by company, while Scott (2010, p. 154) stated that ERC measured the level of stock return in responding of unexpected return reported by company.

According to Hope (2006), IFRS are accounting rules ("standards") issued by the International Accounting Standards Board (IASB), an independent organization based in London, UK. They purport to be a set of rules that ideally would apply equally to financial reporting by public companies worldwide. Between 1973 and 2000, international standards were issued by the IASB's predecessor organization, the International Accounting Standards Committee (IASC), a body established in 1973 by the professional accountancy bodies in Australia, Canada, France, Germany, Japan, Mexico, Netherlands, United Kingdom and Ireland, and the United States. During that period, the IASC's rules were described as "International Accounting Standards" (IAS). Since April 2001, this rule-making function has been taken over by a newly reconstituted IASB. The IASB describes its rules under the new label "International Financial Reporting Standards" (IFRS), though it continues to recognize 


\section{Asia Pacific Journal of Advanced Business and Social Studies \\ ISBN (eBook): 9780994365675 | ISSN : 2205-6033 \\ Year: 2017, Volume: 3, Issue: 2}

(accept as legitimate) the prior rules (IAS) issued by the old standard-setter (IASC). The IASB is better funded, better staffed and more independent than its predecessor, the IASC. Nevertheless, there has been substantial continuity across time in its viewpoint and in its accounting standards.

International Accounting Standards (IAS) is a set of standards stating how particular types of transactions and other events should be reflected in financial statements, issued by the International Accounting Standards Committee (IASC). From April 1, 2001, the International Accounting Standards Board (IASB) superseded IASC's role of international accounting standard setting and began issuing International Financial Reporting Standards (IFRS).

According to Hope (2006), the positive effects of global accounting harmonization have been increasingly recognized by countries around the world. International Financial Reporting Standards (IFRS) are currently being adopted in a number of jurisdictions. By the end of 2005, IFRS were required in at least 65 countries for all domestic listed companies, including 28 European Union and European Economic Area member countries.

International Financial Reporting Standards (IFRS) have recently been adopted in a number of jurisdictions, including the European Union. Despite the importance of IFRS in the context of global accounting standards harmonization, little is known regarding what institutional factors influence countries decisions to voluntarily adopt IFRS. This issue is relevant to standard setters because a better understanding of the motivations for adoption will enable them to promote IFRS more effectively to countries that currently do not employ IFRS. Consistent with bonding theory, Hope (2006), find that countries with weaker investor protection mechanisms are more likely to adopt IFRS. Hope's (2006) evidence also shows that jurisdictions that are perceived to provide better access to their domestic capital markets are more likely to adopt IFRS. Taken together, Hope, 2006 results are consistent with the view that IFRS represent a vehicle through which countries can improve investor protection and make their capital markets more accessible to foreign investors.

Ball (2006) stated, that there's a focus of IFRS on fair value accounting may also lead to increased earnings volatility, and consequently, less accurate earnings forecasts. Hence a lot of further researches need to be conducted in determining the prior research relevance in the fair value accounting environment. The conclusion of Ball (2006) are:

- Internationally uniform accounting rules are a leap of faith, untested by experience or by a significant body of academic results.

- The emphasis of IFRS on fair value accounting is a concern, particularly in relation to reporting in lesser-developed nations.

- The incentives of preparers (managers) and enforcers (auditors, courts, regulators, politicians) remain primarily local, and inevitably will create differences in financial reporting quality that will tend to be "swept under the rug" of uniformity.

- It is essentially costless to say one has the highest standards, so even the lowestquality reporting regimes will be attracted to free use of the IFRS "brand name".

- Uniform international standards reduce competition among systems.

- The long run implication of global politics could well be that the IASB (or its long run successor) becomes a representative, politicized, polarized, bureaucratic, UN-style body.

Writers have already done the preliminary research by making capital market research in Australia about Earning Response Coefficients with the model of Mulyani et al. (2007) was researched, because Australia is one of the countries that already adopted IFRS in 2005, before Indonesia. 
Based on the background and the theory explanation, research hypothesis can be stated as follow:

$\mathrm{H}_{1.1} \quad$ : Beta is affecting Earning Quality.

$\mathrm{H}_{1.2}$ : Capital Structure is affecting to the Earning Quality.

$\mathrm{H}_{1.3}$ : Earning persistence is affecting Earning Quality.

$\mathrm{H}_{1.4} \quad$ : Growth Opportunity is affecting Earning Quality.

$\mathrm{H}_{1.5} \quad$ : Firm Size is affecting Earning Quality.

\section{Research Methodology}

The research is using quantitative approach, emphasized in hypothesis testing. The operational definition of the identified variables is:

\subsection{Earning Response Coefficient}

Earnings Response Coefficient (ERC) is a proxy of earning quality and measured by the regression slope of the stock market price (which is proxied by cumulative abnormal return) and accounting profit (which is proxied with unexpected earnings).

ERC is obtained by several steps of calculation. The first step is calculating cumulative abnormal return (CAR)of each sample and the second step is calculating unexpected earning (UE) of the sample. Its formula can be seen as follows:

\subsection{Cumulative abnormal return (CAR)}

Cumulative abnormal return (CAR) is a proxy of the stock market price or market reaction, this CAR calculation is from Collins and Kothari (1989):

ARit $=$ Rit - Rmt

Where:

$\begin{array}{lr}\text { ARit } & : \text { Abnormal return of firm i on day } t \\ \text { Rit } & : \text { Stock returns of firm i on day } t \\ \text { Rmt } & : \text { Daily market returns of firm i on day } t\end{array}$

Actual Return

Actual return is earning that has been obtained by the investor in the form of capital gain.

Rit $=\frac{\mathrm{Pt}-\mathrm{P}(\mathrm{t}-1)}{\mathrm{P}(\mathrm{t}-1)}$

Where:

Rit ${ }^{\prime} \quad$ : Actual return of firm i on day t

Pt : Stock price of firm i on day $t$

$\mathrm{P}(\mathrm{t}-1) \quad$ : Stock price of firm i on one day before $\mathrm{t}$

\section{Daily Market Return}

The model used is mean-adjusted return like Brown and Warner (1985) in Mulyani et al. (2007).

$\mathrm{Rmt}=\frac{\sum_{j=t 1}^{t 2} \mathrm{E}(\mathrm{Rit})}{T}$.

Where:

Rmt : Daily market return on day t.

$\mathrm{E}(\mathrm{Rit})$ : Realization return of security-I on period-t

$\mathrm{T} \quad$ : The length of estimation period which is from t1 until t2

\section{CAR formula:}

ก CARit $=\sum$ ARit.

क) ARit : Abnormal return of security-I on day-t 


\section{Unexpected Earnings (UE)}

$\mathrm{UEit}=\frac{\mathrm{Eit}-\mathrm{E}(\mathrm{it}-1)}{\mathrm{E}(\mathrm{it}-1)}$

Where:

UEit $\quad$ : unexpected earnings of firm i on year $t$

Eit $\quad:$ Accounting Profit of firm i on year $t$

Eit-1 : Accounting Profit of firm i on year t-1

Hence the earning response coefficient is measured with the regression equation of each company:

CARit $=\alpha+\beta$ UEit $+\varepsilon i t$

Where:

CARit $\quad$ : Cumulative abnormal return of firm i during window period

UEit : Unexpected Earnings

$\beta \quad$ : Earning Response Coefficient

\section{Beta}

Beta is measured using systematic risk using Capital Assets Pricing Model (Ross, 2008:426), which is also used in Mulyani et al. (2007). It is calculated using regression equation:

Rit $=\alpha i+\beta i t ~ R m t+\varepsilon i t$. (3.7)

Where:

Rit $\quad$ : Stock Return of firm i on year $t$

Rmt $\quad$ : Market Return of firm $i$ on year $t$

\section{Capital Structure}

The capital structure is the comparison between debts to own equity which is reflected on the end year financial statement. This equation is using conservative model according to Gibson (2007, 245).

$$
\operatorname{DER}(i, t)=\frac{\text { Long term debt }(\mathrm{i}, \mathrm{t})}{\text { Total equity }(\mathrm{i}, \mathrm{t})}
$$

\section{Earning Persistence}

The earning persistence is measured by the regression slope with the previous year, according to Mulyani et al. (2007):

Xit $=\alpha i+\beta$ it X(it-1) + eit.

Where:

Xit $\quad$ : Accounting Profit of firm i on year $t$

X(it-1) : Accounting Profit of firm i on year t-1

\section{Growth Opportunities}

This variable is measured using market to book value ratio each corporation on the last period of financial statement (Martikainaen,1997).

$$
\text { Market to Book Ratio }=\frac{\text { Equity Market Value }}{\text { Equity Book Value }} .
$$

\section{Firm Size}

Firm size is measured using natural logarithm of total assets. The usage of natural logarithm is used to overcome bias on measurement because of the difference between corporation scales of operation. (Collins and Kothari, 1989).

$$
\text { Corporate SIze }=\text { Ln Total Assets. }
$$




\section{Asia Pacific Journal of Advanced Business and Social Studies \\ ISBN (eBook): 9780994365675 | ISSN : 2205-6033 \\ Year: 2017, Volume: 3, Issue: 2}

The data used in this research is quantitative data in form of audited financial statement and audit report. The data source is gathered from Indonesian Securities Exchange (IDX) through internet access in www.idx.co.id and Indonesian Capital Market Directory. The data gathered are secondary data.

This research is using manufactured industry that listed on Indonesia Securities Exchanges on 2011. The chosen of one industry is to minimalize characteristics between corporations. The chosen is of manufactured industry because of it is the industry that has the majority of departures. The technique for the sample taken is conducted with purposive sampling in order to obtain representatives sample according to the set criteria. That set criterion that is used to obtain the sample is such follow:

- $\quad$ Manufactured Firms that are listed on Indonesia Securities Exchange 2011.

- $\quad$ Stocks are actively traded in IDX.

- $\quad$ Firms are not delisting from IDX during 2011-2014.

- $\quad$ Firm's Financial statement year ending is in December 31.

- Firms were not being the subject of trading suspension during period of observation.

- Data is available on www.idx.co.id and Indonesia capital market directory.

- Firm's information can be obtained by the researcher.

In conducting this research, an observation is needed, the researcher has chosen eleven trading days in IDX, which is 5 days before the announcement of annual financial report ( $\mathrm{t}$ 5 ), on the day annual financial report is published ( $\mathrm{t}$ ), and 5 days after the announcement of financial annual report. The consideration of using narrow window of eleven day is:

- The existence of time lag between the submission of annual financial report to IDX and publication date to the people.

- According to Scott (2009, p. 152), the objective of the research is to see the impact because during the announcement date is more decision usefulness.

- Narrow window can minimalize the compounding effect (Mulyani, 2007).

The technical analysis consists of classical assumption deviation testing and hypotheses and analysis model testing.

The steps to find the solution in this research are:

1. Calculate the dependent and independent variable that is going to be analyzed.

2. Calculate earning response coefficient by regressing stock prices proxy with accounting profit. Stock price proxy used is cumulated expected return (CAR), which is calculated by the formula, CARit $=\sum$ ARit with the narrow window $t-5, t$, and $t+5$. While the earning proxy is calculated using Unexpected return. The next regression equation which is used is calculating earning response coefficient which is CARit $=\alpha+\beta$ UEit $+\varepsilon i t$.

3. Calculate systematic risk using the regression equation Rit $=\alpha \mathrm{i}+\beta \mathrm{it} \mathrm{Rmt}+\varepsilon \mathrm{it}$.

4. Calculate capital structure by the comparison of total debt and total assets.

5. Calculate earning persistence using the regression equation Xit $=\alpha \mathrm{i}+\beta \mathrm{it} \mathrm{X}(\mathrm{it}-1)+\varepsilon i \mathrm{t}$

6. Calculate growth opportunity by calculating market to book value ratio.

7. Calculate firm size by natural logarithm of total assets.

8. Conduct descriptive statistic to determine the profile of the sample company. The statistical method that is used include the company profile, mean, standard deviation.

9. Classical Assumption Deviation Testing.

Before the regression is conducted, classical assumption testing is must be conducted to fulfill the basic assumptions that consist of normality, multi co-linearity, heterokedasticy, and autocorrelation testing. The classical assumption deviation-testing step is as follow: 
1. Normality testing

2. Multi co-linearity testing

3. Heterokedasticity testing

4. Auto-correlation testing

10. Hypothesis and Analytical Model Testing.

1. Regression Analysis

The regression model for this research is:

$$
\mathrm{ERC}_{\mathrm{it}}=\beta_{\mathrm{o}}+\beta_{1} \beta_{\mathrm{it}}+\beta_{2} \mathrm{CAS}_{\mathrm{it}}+\beta_{3} \mathrm{PER}_{\mathrm{it}}+\beta_{4} \mathrm{GOP}_{\mathrm{it}}+\beta_{5} \mathrm{CSI}_{\mathrm{it}}+\varepsilon_{\mathrm{it}}
$$

Where:

ERC $_{\text {it }} \quad$ : dependent variable Earning Response Coefficient of firm i end of year $\mathrm{t}$

$\beta_{\mathrm{o}} \quad$ : Constanta

$\beta_{1}, \beta_{2}, \beta_{3}, \beta_{4}, \beta_{5}$ : coefficients of regressions

$\beta_{\text {it }} \quad$ : independent variable Beta of firm i end of year $t$

$\mathrm{CAS}_{\mathrm{it}} \quad$ : independent variable Capital Structure of firm i end of year $\mathrm{t}$

$\mathrm{PER}_{\text {it }} \quad$ : independent variable Persistence of firm i end of year $t$

$\mathrm{GOP}_{\text {it }} \quad$ : independent variable Growth Opportunity of firm i end of year $t$

$\mathrm{CSI}_{\mathrm{it}} \quad$ : independent variable Firm Size firm of $\mathrm{i}$ end of year $\mathrm{t}$

$\varepsilon_{\text {it }} \quad:$ standard error

2. $\mathrm{R}^{2}$ (Coefficient of Determination) Testing

F-Test

F-test is done to see the impact of independent variables as a whole to dependent variable.

3. The determination of significant level $(\alpha)$

The level of significant used is $5 \%, \alpha=5 \%$.

- Statistical testing using F-test

- Sig-F will be resulted using SPSS

4. t-Test

t-Test is done to see the impact of independent variables individually to dependent variable. The steps of t-test is as follow:

Hypothesis 1.1

$$
\text { Hypotheses construction }
$$

$\mathrm{H}_{1.1} \quad$ : Beta is affecting Earning Response Coefficient

$$
\mathrm{H}_{\mathrm{o}} \text { : Beta is not affecting Earning Response Coefficient }
$$

$\mathrm{H}_{\mathrm{a}}$ : Beta is affecting Earning Response Coefficient

Hypothesis 1.2

$\mathrm{H}_{1.2} \quad$ : Capital Structure is affecting to the Earning Response Coefficient

$\mathrm{H}_{\mathrm{o}}$ : Capital Structure is not affecting Earning Response Coefficient

$\mathrm{H}_{\mathrm{a}}$ : Capital Structure is affecting Earning Response Coefficient

Hypothesis 1.3

$\mathrm{H}_{1.3} \quad$ : Earning persistence is affecting Earning Response Coefficient

$\mathrm{H}_{\mathrm{o}}$ : Earning persistence is not affecting Earning Response Coefficient

$\mathrm{H}_{\mathrm{a}}$ : Earning persistence is affecting Earning Response Coefficient

Hypothesis 1.4

$\mathrm{H}_{1.4}$ : Growth Opportunity is affecting Earning Response Coefficient

$\mathrm{H}_{\mathrm{o}}$ : Growth Opportunity is not affecting Earning Response Coefficient 
Hypothesis 1.5

$\mathrm{H}_{\mathrm{a}}$ : Growth Opportunity is affecting Earning Response Coefficient

$\mathrm{H}_{1.5} \quad$ : Firm Size is affecting Earning Response Coefficient

$\mathrm{H}_{\mathrm{o}}$ : Firm Size is not affecting Earning Response Coefficient

$\mathrm{H}_{\mathrm{a}}$ : Firm Size is affecting Earning Response Coefficient

- $\quad$ Determining the level of significant

The level significant used is $5 \%, \alpha=5 \%$.

- $\quad$ Statistical testing using t-test

- $\quad$ Sig-t will be resulted by SPSS

- $\quad$ Conclusion

- $\quad$ If the value of Sig- $t<\alpha$, then $H_{o}$ is rejected and $H_{a}$ is accepted.

- $\quad$ If the value of Sig- $t \geq \alpha$, then $H_{a}$ is rejected and $H_{o}$ is accepted.

- Conclusion

\subsection{Result and Discussion. 3.3.1 Research Result Description.}

The summary of sample selection in this research can be seen on table 4.1:

Table 4.1: Sample Selection Summary

\begin{tabular}{|l|c|}
\hline \multicolumn{1}{|c|}{ Classification } & Amount \\
\hline $\begin{array}{l}\text { Diversified Manufactured firm that listed in } \\
\text { IDX on 2011 }\end{array}$ & 137 \\
\hline $\begin{array}{l}\text { Delisting firm, IPO after 2012, inconsistency } \\
\text { in reporting }\end{array}$ & $(16)$ \\
\hline Total Sample & $\mathbf{1 2 5}$ \\
\hline
\end{tabular}

The results of descriptive analysis for each research variable is presented on table 4.2:

Table 4.2: Descriptive Statistic Analysis of Variables

\begin{tabular}{|l|r|r|r|}
\hline & \multicolumn{1}{|c|}{ Mean } & $\begin{array}{c}\text { Std. } \\
\text { Deviation }\end{array}$ & \multicolumn{1}{c|}{$\mathrm{N}$} \\
\hline ERC & .0077 & .16272 & 98 \\
BETA & .1057 & .62425 & 98 \\
Cap Structure & .7932 & 4.38736 & 98 \\
Earning Persistence & .2667 & 1.38085 & 98 \\
Growth Opportunities & 3.1038 & 7.39304 & 98 \\
Firm Size & 28.1462 & 1.61569 & 98 \\
\hline
\end{tabular}

\section{Earning Response Coefficient.}

Earnings response coefficient values indicate the reaction to the accounting profit generated by the firm. The high or low of ERC is depending on the good news or bad news contained in earnings. A small earnings response coefficient value indicates bad news that caused the decline in stock prices. Vice versa, the greater the earnings response coefficient indicates the existence of good news, which increased the company's stock price. Table 4.2 depicts the mean of Earning Response Coefficient sampled company throughout the period of research is 0.0077 . While the standard deviation of ERC result is 0.16272 . 


\section{Asia Pacific Journal of Advanced Business and Social Studies \\ ISBN (eBook): 9780994365675 | ISSN : 2205-6033 \\ Year: 2017, Volume: 3, Issue: 2}

Beta.

Beta coefficient is the amount of systematic risk (Ross 2008:418). The price of a stock with a beta of 1.0 rises and falls on average with the overall market. A beta greater than 1.0 could mean larger prices fluctuations which means higher systematics risk, and a beta of less than 1.0 indicates a more tame stock and has lower systematic risk. Table 4.2 presents that the average of beta sampled company throughout the period of research is 0.1057 and the standard deviation is 0.62425 .

\section{Capital Structure.}

Credit analysis is one of the most common uses of financial statements, reflecting the many forms of debt are essential to the operation of a modern economy. Financial statements tell leverage as a borrower's ability to repay a loan. The bigger the value of capital structure, the more debt that the company has that can caused the risk of high interest expense. The high payment of installment and interest can cause financial distress because of insufficient cash flow. Table 4.2 depicts the average of capital structure sampled company throughout the period of research is 0.7932 and the standard deviation is 4.38736 .

\section{Earning Persistence.}

Earning persistence indicates how much the coefficient of variation is between the earnings period with the previous period. The more permanent changes in earnings from time to time, hence the higher the coefficient of earning persistence because this condition indicates that the earning from the company to increase continuously. Table 4.2 depicts the average of earning persistence sampled company throughout the period of research is 0.2667 and the standard deviation is 1.38085 .

\section{Growth Opportunities.}

Growth opportunities is the firm's growth prospects in the future that can be measured from market to book value ratio, which is measured from division between the market value of equity to total equity. Equity market value is obtained by multiplying stock price by the number of shares outstanding at the end of the year. Market to book value ratio indicates how big the firm's investment opportunities that could enhance the capital of the firm. Table 4.2 presents the mean of growth opportunities sampled company throughout the period of research is 3.1038 and the standard deviation is 7.39304 .

\section{Firm Size.}

Firm size is calculated using the natural logarithm of total assets. Table 4.2 depicts the average firm size of sampled companies throughout the period of this research is 28.1462 and the standard deviation is 1.61569 .

\subsection{Hypothesis, and Analytical Model Testing}

\subsubsection{Multiple Regression Analysis}

Once the model has met all the classical assumptions, regression analysis can be done. Multiple regression analysis conducted to find the effect of beta, capital structure, earnings persistence, growth opportunities, and firm size to ERC. Here is a regression model between beta, capital structure, earnings persistence, growth opportunities, and firm size to the ERC based on SPSS output:

Table 4.4: Multiple Regression Analysis Table

\begin{tabular}{|l|r|r|r|r|}
\hline \multicolumn{1}{|c|}{ Variables } & Coefficient & \multicolumn{1}{c|}{ Std Error } & \multicolumn{1}{c|}{ T value } & Significance \\
\hline Constant & .343 & .302 & 1.136 & .259 \\
\hline Beta & -.018 & .027 & -.675 & .501 \\
\hline
\end{tabular}




\begin{tabular}{|c|c|c|c|c|}
\hline Capital Structure & .000 & .004 & .128 & .899 \\
\hline Earnings Persistence & .003 & .012 & .251 & .803 \\
\hline $\begin{array}{l}\text { Growth } \\
\text { Opportunities }\end{array}$ & -.001 & .002 & -.452 & .652 \\
\hline Firm Size & -.012 & .011 & -1.095 & .276 \\
\hline R-square & & & & .027 \\
\hline
\end{tabular}

Regression coefficient values in the table above can be written into the equation as follows: $\mathrm{ERC}=$ 0,343 - 0,018 Beta + 0,000 Capital Structure + 0,003 Earnings Persistence - 0,001 Growth Opportunities - o,012 Firm Size + e

a. Constant

Constant value in the regression equation is 0,343 . This means, if the independent variables in the regression models are 0 , then the Earning Response Coefficient would be worth 0,343 .

b. Coefficient Regression

1. Beta variable regression coefficient is $-0,18$. This means that if a company's Beta value increased by one percent, the company earnings response coefficient would decrease by 0.18 , assuming the other independent variables constant.

2. Capital Structure variable regression coefficient is 0.000. This means that if the value of a company's capital structure increased by one percent, then the earning response coefficient companies will increase by 0.000 , assuming the other independent variables constant.

3. Earnings persistence variable regression coefficient is o.003. That is, if the persistence of a company's earnings increased by one percent, the company earnings response coefficient would increase by 0.003 , assuming the other independent variables constant.

4. Growth opportunities variable regression coefficient is -0.001. This means that if the growth opportunities of company increases one percent, the company earnings response coefficient would decrease by 0.001, assuming the other independent variables constant.

5. Regression coefficient of firm size variable is -0.012. This means that if firm size increased by one percent of a company, the company earnings response coefficient will decrease by 0.012 , assuming the other independent variables constant.

c. Coefficient of Determination (R Square)

The coefficient of determination shows 0.27 which mean independent variables: Beta, Capital Structure, Earnings Persistence, Growth Opportunities, and Firm Size, are capable to explain the changing of Earning Response Coefficient for $27 \%$, while the rest of $73 \%$ influenced by other variables outside of observation in this research.

\section{Hypothesis Testing}

Hypothesis testing is done by two methods, the $\mathrm{t}$ test and $\mathrm{F}$ test $\mathrm{T}$ test used to find the influence of independent variables on the dependent variable in a partial, whereas the $\mathrm{F}$ test used to find the influence of independent variables against dependent variables simultaneously and to proof that the t-test results are well done.

\section{Partial Testing (t-test)}

T-test was performed to find the influence of variables Beta, Capital Structure, Earnings Persistence, Growth Opportunities, and Firm Size on the earnings response coefficient partially (their own). An independent variable is said to be significant to the dependent variable if it has significance less than 0.05 . Here are the results of $t$ test: 
Table 4.5: Multiple Regression Coefficient Table

\begin{tabular}{|l|c|c|c|}
\hline \multicolumn{1}{|c|}{ Variables } & $\mathrm{t}$ & Sig. & Result \\
\hline Beta & -.675 & .501 & Not Significant \\
\hline Capital Structure & .128 & .899 & Not Significant \\
\hline Earnings Persistence & .251 & .803 & Not Significant \\
\hline $\begin{array}{l}\text { Growth } \\
\text { Opportunities }\end{array}$ & -.452 & .652 & Not Significant \\
\hline Firm Size & -1.095 & .276 & Not significant \\
\hline
\end{tabular}

1. Significant value of Beta on earnings response coefficient is 0.501 , this value is greater than level of significance $5 \%$ (Sig-t $\geq \alpha$,) then $\mathrm{H}_{\mathrm{a}}$ is rejected and $\mathrm{H}_{\mathrm{o}}$ is accepted which means that Beta is not affecting ERC

2. Significant value of Capital Structure on earnings response coefficient is o.899 this value is greater than level of significance $5 \%$ (Sig-t $\geq \alpha$,) then $\mathrm{H}_{\mathrm{a}}$ is rejected and $\mathrm{H}_{\mathrm{o}}$ is accepted which means that Capital Structure is not affecting ERC

3. Significant value of Earning Persistence on earnings response coefficient is 0.803 this value is greater than level of significance $5 \%$ (Sig-t $\geq \alpha$,) then $H_{a}$ is rejected and $H_{o}$ is accepted which means that Earning Persistence is not affecting ERC

4. Significant value of Growth Opportunities on earnings response coefficient is 0.652 , this value is greater than level of significance $5 \%$ (Sig-t $<\alpha$,) then $\mathrm{H}_{\mathrm{a}}$ is rejected and $\mathrm{H}_{0}$ is accepted which means that Growth Opportunity is not affecting ERC.

5. Significant value of Firm Size on earnings response coefficient is 0.276. this value is greater than level of significance $5 \%$ (Sig-t $\geq \alpha$,) then $H_{a}$ is rejected and $H_{o}$ is accepted which means that Firm Size is not affecting ERC.

It can be concluded that all variables partially are not affecting ERC.

\section{Simultaneous Testing (F-Test)}

The conclusion of all variables partially are not affecting ERC, is also proofed by $\mathrm{F}$ test. F test is performed to find the influence of variables Beta, Capital Structure, Earnings Persistence, Growth Opportunities, and Firm Size all together on the earnings response coefficient. It stated that there was simultaneous influence of independent variables on the dependent variable if the value of $F$ test of significance yielded a value of less than 0.05. Here are the results of $\mathrm{F}$ test:

Table 4.6: F-Test Result

ANOVA ${ }^{b}$

\begin{tabular}{|ll|r|r|r|r|r|}
\hline \multicolumn{1}{|l|}{} & \multicolumn{1}{|c|}{$\begin{array}{c}\text { Sum of } \\
\text { Squares }\end{array}$} & $\mathrm{df}$ & Mean Square & \multicolumn{1}{c|}{$\mathrm{F}$} & \multicolumn{1}{c|}{ Sig. } \\
\hline 1 & Regression & .069 & 5 & .014 & .501 & $.774^{\mathrm{a}}$ \\
& Residual & 2.497 & 91 & .027 & & \\
& Total & 2.566 & 96 & & & \\
\hline
\end{tabular}

a. Predictors: (Constant), CSI, PER, CAS, Bit, GOP

b. Dependent Variable: ERC

Based on table 4.6, it can be known that the significant value of $\mathrm{F}$ test is 0.774 . This value is higher than level of significance $5 \%$ (Sig-t $\geq a$,) then Ho is accepted and Ha is rejected which proofs that all variables (Beta, Capital Structure, Earning persistence, Growth Opportunity, and Firm Size) are not affecting simultaneously to the Earning Response Coefficient. 


\section{Asia Pacific Journal of Advanced Business and Social Studies \\ ISBN (eBook): 9780994365675 | ISSN : 2205-6033 \\ Year: 2017, Volume: 3, Issue: 2}

\section{Discussion \\ 5.1 The Influence of Beta to the Earning Response Coefficient}

Based on t-test on table 4.5 , it depicts that the Sig-t of beta is 0.501 , which is way beyond $5 \%$ level of significance. It shows that the beta does not affect earnings response coefficient. This research result is inconsistent with Collins and Kothari (1989), Easton and Zmijewski (1989), and Mulyani et al. (2007).

The riskier the sequence of a firm's expected returns, the lower will be its value to a riskaverse investors. Since the investors look to current earnings as an indicator of future firm performance and share return, the riskier these future returns are the lower investors reactions to a given amount of unexpected earnings will be Scott (2009:154). From Scott's explanation, we can say that probably the investor tends to play safe because financial forecasting is troublesome rather than economic forecasting. Stein (2009) during the 2009 recession, for a conservative investor, tended to not enter the market, while the risk seeker tends not to look beta, they tend to look more of other information, they are not dare to take any risk during those periods, hence the beta is not affecting Earning Response Coefficient.

\subsection{The Influence of Capital Structure to the Earning Response Coefficient}

Based on t-test on table 4.5, it depicts that the Sig-t of capital structure is 0.899, which is way beyond 5\% level of significance. It shows that the capital structure does not affect earnings response coefficient. This research result is inconsistent with Dhaliwal et al. (1991) in Scott (2009, p. 154).

Scott (2009:154), said that for highly levered firms, an increase, say, in earnings, adds strength and safety to bonds and other outstanding debt, so that much of the good news in earning goes to debtholders rather than the shareholder. Thus, the ERC for a highly levered firm should be lower, it is unproven, because in the recession time, most of the companies suffered loss, hence investor does not care whether they are going to be benefitted by that condition or not, all that they feel is an insecure feeling. So they tend to look at more than capital structure information, hence capital structure does not affecting earning response coefficient.

\subsection{The Influence of Earning Persistence to the Earning Response Coefficient}

Based on t-test on table 4.5, it depicts that the Sig-t of earning persistence is o.803, which is way beyond $5 \%$ level of significance. Itshows thatthe earning persistencedoes not affect influenceearnings response coefficient. This research result is inconsistent with KormendiLipe (1987), and Mulyani et al. (2007).

This research shows that the market does not respond the stability of the company retaining its profit. A lot of investors consider other factors besides earning in taking its decision. The IFRS, in here, shows that its inability to increase decision usefulness to be more earning oriented rather than non-earning information. As Ball (2006) said "there's a focus of IFRS on fair value accounting may also lead to increase earnings volatility and consequently, less accurate earnings forecasts". It is proven here that the IFRS volatility in earning that end up in earning persistence unable to affecting ERC. As we can see in U.S Historical Based accounting, it can give empirical evidence that earning persistence can give strong significance like in Kormendi and Lipe (1987), while IFRS still can't give any empirical evidence.

\subsection{The Influence of Growth Opportunities to the Earning Response Coefficient}

Based on t-test on table 4.5, it depicts that of Sig-t of growth opportunities is 0.652 , which is beyond $5 \%$ level of significance. It shows that the growth opportunities also do not affect earnings response coefficient. This research result is inconsistent with Collins and Kothari 


\section{Asia Pacific Journal of Advanced Business and Social Studies \\ ISBN (eBook): 9780994365675 | ISSN : 2205-6033 \\ Year: 2017, Volume: 3, Issue: 2}

(1989), and Mulyani et al. (2007). This condition shows that the bigger company's opportunity to grow does not make the same direction in expectations to obtain its earning. Moreover, fair value atmosphere does not make investor look at the prospect of the company to grow.

\subsection{The Influence of Firm Size to Earning Response Coefficient}

Based on t-test on table 4.5, it depicts that the of Sig-t of firm size is 0.276 , which is way beyond $5 \%$ level of significance. Itshows thatthe firm sizedoes not affectingearnings response coefficient. This research result is inconsistent with NaimahUtama (2006) and Chaney and Jater (1991).

Firm size doesn't have an effect on earning response coefficient because total assets can't be a definite measurement about the company's earning in a period. Chaney and Jater (1991) say that bigger company tend to make bigger earning seems to be not work on this case, because of external factor for the company is also playing big role on the determination of company's earning.

\subsection{The Influence of Beta, Capital Structure, Earning persistence, Growth Opportunity, and Firm Size Simultaneously to the Earning Response Coefficient}

Based on ANOVA test on table 4.6, it depicts that the level of significant value of $\mathrm{F}$ test is 0.774., which is beyond than $5 \%$ level of significance. Itshows thatthe Beta, Capital Structure, Earning persistence, Growth Opportunity, and Firm Size is not affecting Earning Response Coefficient Simultaneously.

In this case, it is hoped that the company will be more careful and full of consideration in publishing its earnings, because one's earning is a central issue and focus for investor to determine a firm to invest its fund (Beatie et al, 1994). Besides that, the company has to be more transparent and fair in reporting its earning, hence firm does not give investor corrupt information that can make the company earning quality is questionable.

\section{Conclusion}

Based on the analysis result conducted using 83 manufacturing firms that are listed on Indonesian Stock Exchange with the sampling period of 2011 to 2014, the conclusion that can be derived is:

Based on statistic test (t-Test), it shows that all variables are not affecting Earning Response Coefficient. Preiato (2009) statement that "it was unclear that mandatory IFRS adoption would in fact result in an increase in the decision usefulness of financial statement information" is correct because, there are still many factors outside the financial statement still affecting the decision usefulness in the capital market.

\section{Suggestions and Implications}

Based on the above conclusion, the suggestions that can be given are as follow:

1. The next researchers should be more careful to find and determine other factors that affecting earning response coefficient in the fair value accounting environment.

2. Firm management should be more transparent in publishing their earning because earning is a central issue and focus for investor to determine a firm to invest its fund.

The Implication of this research is:

The expectation of increasing earning quality in IFRS implementation in Indonesia is not proven statistically. It may imply, in Indonesia, mandatory IFRS adoption, in fact, does not resulting an increase in the decision usefulness of financial statement information. 
Furthermore, consistently follow Ball (2006) that said, "there's a focus of IFRS on fair value accounting may also lead to increase earnings volatility and consequently, less accurate earnings forecasts", the volatility in earning that end up in earning persistence unable to affecting Earning Response Coefficient. 


\section{References}

i. $\quad$ Kim, et al, n.d. Default Risk as a Factor affecting the Earning Response coefficient. Working Paper. s.l.:Queensland University of Technology.

ii. Patricia, et al., 2010. Understanding Earnings Quality: A Review of Their Proxies, Their Determinants, and Their Consequences. Working Paper, Berkeley: University of California .

iii. Westerfield, et al., 2005. Corporate Finance.. 7th ed. New York: McGraw-Hill Companies Inc..

iv. $\quad$ Yeo Hwan, et al., n.d. Default Risk as a Factor affecting the Earnings Response Coefficient, s.l.: Social Science Research Network.

v. Ahalik \& HestiUtaminingtyas, T., 2010. The relationship between Corporate Social Responsibility and Earnings Response Coefficient: Evidence from Indonesian Stock Exchange. 2010 Oxford Business \& Economics Conference Program June 28-29, 2010. Oxford, UK, St. Hugh's College, Oxford University.

vi. $\quad$ Anon., 2008. Corporate Finance Fundamentals.. 8th ed. New York: McGraw-Hill Companies Inc..

vii. Baruch, L. \& RamuThiagarajan., 1995. Fundamental Information Analysis.. Journal of Accounting Research , 51(2).

viii. $\quad$ Bruce, J. \& Zhao, R., n.d. Cross-Sectional Variation in the Share Process Response to Extreme Earning Surprises. Working Paper, Lowa: University of Lowa .

ix. Charles, G., 2007. Financial Reporting \& Analysis. 10th ed. Ohio: Thomson Higher Eduaction.

x. Cheng, F. \& Nasir, A., 2010. Earning Response Coefficients and the Financial Risks of China Commercial Bank. International Review of Business Research Paper Scientific Journal, 6(3), pp. 178-188.

xi. Collins et al, n.d. The Predictability of Interim Earnings Over Alternative Quarters. Journal of Accounting Research, 22(2), pp. 467-579.

xii. Collins, Daniel, W. \& S.P. Kothari., 1989. An Analysis of Intertemporal and crosssectional Determinants of Earnings Response Coefficients. Journal of Accounting \& Economics, 11(2), pp. 143-181.

xiii. Dewi \& Ratna, A., 2003. PengaruhKonservatismeLaporanKeuanganterhadap Earning Response Coefficient, Surabaya: Simposium Nasional Akuntansi VI .

xiv. $\quad$ Donald E, et al, 2011. Intermediate Accounting Vol.1:IFRS Edition.. 11th ed. Singapore: John Wiley \& Sons..

xv. Easton, Peter, D. \& Zmijewski, M. E., 1989. Cross-sectional Variation in the Stock Market Response to Accounting Earnings Announcements. Journal of Accounting \& Economics, 11(2), pp. 117-141.

xvi. Fabozzi \& Modigliani, 2009. Capital Markets Institutions and Instruments. 4th ed. New Jersey: Prentice-Hall Inc.

xvii. Gitman \& Lawrence, J., 2009. Foundations of Managerial Finance. 12th ed. s.l.:Addison Wesley.

xviii. Indonesia., I., 2012. StandarAkuntansiKeuangan, Jakarta: PenerbitSalembaEmpat.

xix. Institute of Chartered Accountant in England and Wales, 2005. International Financial Reporting Standards Pros and Cons for Investors, s.l.: Institute of Chartered Accountant in England and Wales.

xx. $\quad$ Ketherune, S. \& Vincent, L., 2003. Earning Quality. Accounting Horizon, Volume 17, pp. 97-110. 


\section{Asia Pacific Journal of Advanced Business and Social Studies \\ ISBN (eBook): 9780994365675 | ISSN : 2205-6033 \\ Year: 2017 , Volume: 3, Issue: 2}

xxi. Konan, et al., n.d. Earnings Quality and Stock Returns, s.l.: National Bureau of Economic Research. Working Papers.

xxii. Minna., M., 1997. Acounting Losses and Earning Response Coeffeients: The Impact of Leverage and Growth Opportunities. Journal of Business Finance \& Accounting, 24(2), pp. 306-686.

xxiii. $\quad$ Ole., et al., 2006. Empirical Evidence on Jurisdictions that adopt IFRS, s.l.: Social Science Research Network.

xxiv. Paul, C. \& Jeter, D., 1991. The effect of Size on the Magnitude of long window Earnings Response Coefficients.. Contemporary Accounting Research, 8(2), pp. 540-560.

xxv. Peter, D., 2008. IFRS Implementation Experience, s.l.: AMCOR CFO Reflections..

xxvi. $\quad$ Preiato, e. a., 2009. IFRS Adoption, Analysts , and Institutional Setting.. s.l., Accounting and Finance Academics of Australia and New Zealand Seminar..

xxvii. $\quad$ Ray, B. \& Brown, P., 1968. An Empirical Evaluation of Accounting Income Numbers. Journal of Accounting Research, pp. 159-178.

xxviii. Ray, D., 2002. Earning Persistence, Losses and the Estimation of Earning Response Coefficient. ABACUS, 38(1).

xxix. Scott, W., 2003. Financial Accounting Theory. 3rd ed. Toronto: Prentice-Hall Inc..

xxx. Scott, W., 2009. Financial Accounting Theory. 5th ed. Toronto: Prentice-Hall Inc.

xxxi. Severine, H., 2005. Financial Information and Earnings Quality: A literature review, s.l.: Faculté des Sciences économiques, sociales et de gestionDépartement des Sciences de gestion Working Paper..

xxxii. Sri, M., FadjihAsyik, N. \& danAndayani, 2007. Faktor-faktor yang Mempengaruhi Earnings Response CoeffecientPada Perusahaan yang terdaftar di Bursa Efek Jakarta. JAAI, 11(1), pp. 3545 .

xxxiii. Stein, B., 2009. 4 Lessons From The Recession. Fortune 500 Article. [Online] Available at: (http://money.cnn.com/2009/11/18/news/economy/recession_lessons.fortune

xxxiv. Sunardi, Dickky, L. \& Rizki, A., 2012. Earning Quality in The Fair Value Accounting Environment. s.l., Airlangga Accounting International Conference \& Doctoral Colloquium.

xxxv. Terry, S. \& Shores., D., 1993. Firm Size, Security Returns, and Unexpected EarningsL The Anomalous Signed-Size Effect.. Contemporary Accounting Research, 10(1), pp. 1-30.

xxxvi. Vernon, K., 1990. Accounting Theory. s.l.:John Wiley \& Sons.

xxxvii. Zahroh, N. \& SiddhartaUtama., 2006. PengaruhUkuran Perusahaan Pertumbuhan, danprofitabilitas Perusahaan terhadapKoefesienResponsLabadanKoefesienResponNilaiBukuEkuitas: StudiPada Perusahaan Manufaktur di Bursa Efek Jakarta. Padang, Simposium Nasional Akuntansi IX. 